\title{
Gender Imbalances in the Visual Discourse of Moroccan EFL Textbooks: A Critical Image Analysis.
}

\author{
Driss Benattabou ${ }^{1, *}$ \\ ${ }^{I}$ Moulay Ismail University, Morocco \\ Received: $15.09 .2020 \quad$ • Accepted/Published Online: $15.11 .2020 \quad$ • Final Version: 15.11.2020
}

\begin{abstract}
The aim of this paper is to investigate the portrayal of women and men in the visual discourse of Moroccan English as a Foreign Language (MEFL, henceforth) textbooks employing a bi-modal analysis comprising qualitative content analysis alongside Giaschi (2000), Kress and Van leeuwen (2006), and Newfield's (2011) newly developed concept of critical image analysis. This bi-modal approach attempts to address a number of themes recurrent in the visual contents of the selected textbooks. Relying on this combination, pictorial images featuring both women and men indoors (in domestic settings) and outdoors either in the job market or undertaking some outdoor activities are interrogated. The results of this inquiry prove very convincingly that the visual discourse of MEFL textbooks is fraught with an array of cultural misconceptions in discrimination of women. The paper ends up with a conclusion along with some recommendations.
\end{abstract}

Keywords: Gender bias, MEFL textbooks, Critical Image Analysis, Visual Representation.

\section{Introduction}

The bi-modal approach of this study seeks to examine some of the re-occurring patterns characterizing the pictorial depictions of women and men in a wide range of social contexts. The visual discourse of nine Moroccan English as a Foreign Language (MEFL, henceforth) textbooks will be analyzed conjoining between two analytical techniques, namely content analysis alongside with Giaschi (2000), Kress and Van leeuwen (2006), and Newfield's (2011) newly developed concept of critical image analysis. Special emphasis is placed on the categorization of the two sex groups regarding such dimensions as who is active and who is passive in pictures. Attention is also directed to examine how women and men are presented in visual images, what type of activities they are involved in, in what setting, what occupational roles they play, and what type of power and dominance relations can be elicited from their interactions.

\footnotetext{
* Corresponding Author: d.benattabou@umi.ac.ma
} 


\section{A Theoretical Preamble}

\subsection{Visual Communication}

Visual communication is one of the predominant features of our modern age. It is ubiquitous and seems to cover a wide range of media genres including, but not limited to, electronic messages, print media, billboards and road signs. The content of communication is increasingly becoming visual than textual. "One picture is worth a thousand words", as the old saying goes, is reflective of the power and the influential role of visual communication in the transmission of information.

With the advent of modern technology and with the enormous expansion of visual communication, the concept of 'literacy' has become even wider covering not only the ability of reading and writing, but also the skills of how to read and elicit information from visual images.

To figure out the intended meaning from visual communication, one should be visually literate. At the center of this discussion, two major questions may warrant an answer here: (1) what is meant by visual literacy, and what are its prerequisites? And (2) what does it mean to be a visually literate person, and what does it entail?

\section{Visual Literacy}

Visual literacy is a term that has been widely used to mean the ability to read, comprehend and elicit information from pictures, photographs or drawings. Wileman (1993) defines visual literacy as 'the ability to 'read,' interpret', and understand information presented in pictorial or graphic images" (Wileman, 1993, p. 114). Bristor and Drake (1994) provide a similar definition stating that it is "the ability to understand, interpret and evaluate visual messages". This seems to imply that in dealing with pictorial representations one may call for one's "ability to construct meaning from visual images" (Giorgis et al. 1999, p. 146).

A more comprehensive view of visual literacy has been echoed in The American Association of College and Research Libraries (ACRL):

"Visual literacy is a set of abilities that enables an individual to effectively find, interpret, evaluate, use, and create images and visual media. Visual literacy skills equip a learner to understand and analyze the contextual, cultural, ethical, aesthetic, intellectual, and technical components involved in the production and use of visual materials. A visually literate individual is both a critical consumer of visual media and a competent contributor to a body of shared knowledge and culture." (ACRL, 2011).

The problem with visual communication is that although images may sometimes seem to be clear and outright, they are more likely to carry far more subtle and latent ideological messages that are not always explicit.

As with written discourses, visual communication may be approached from two different but closely interlinked levels. The first level seems to present no resistance as to its meaning. The intent of the communication is explicit and clearly crafted displaying no 
difficulty in its understanding. The second level; however, is much more subtle and may exude some hidden meanings far more complicated to a non-alerted observer.

The initiated viewer may find difficulties to come into grips with the symbolic messages of pictures. Deconstructing the covert meaning of this second level may surely warrant a critical eye. The visually literate reader must go beyond the confines of what is communicated explicitly. In addition to overt meanings of visual communication, readers have to look for ways of how to decrypt even the covert messages of pictures.

Beyond the superficial perception of the non-initiated viewer, visual literacy may call for an alerted critical eye that can probe much deeper. Duchak (2014) aptly reports in this respect that "although our students are consumers of media and have easy access to visually rich Web, visual saturated media, photo dependant social networks and sophisticated gaming, they are not visually literate" (Duchak, 2014, p. 45).

\section{Visual images in textbooks}

Visual images are part and parcel of any educational material. They are considered desirable mediums which can promote success among language learners (Duchak, 2014, p. 41). In a like manner, pictorial representations used in textbooks are more powerful tools to enhance a learner's understanding of written texts. These visual depictions; however, are reported to have the power to impact students' attitudes and values regarding a wide range of socio-cultural matters including such subtle concepts as gender disparities and stereotypes, along so many others (Giaschi, 2000). Pictorial images may carry an array of hidden ideologies of which gender bias may constitute but only one facet of the whole gamut. The issue at stake, as Dube (2006) observes, is that:

"Very few teachers realize that deeply imbedded within the illustrations, are possible gender imbalances, which serve to affirm the dominant ideologies and attitudes of the society. The glossy illustrations hide within them a hidden agenda whose effect on the reader is very insidious"(Dube, 2006, p. 4).

Although pictures may have more effective pedagogical roles, they are not unlikely to be overloaded with a number of hidden ideologies. "As a socializing agent", kang (1997) contends in this regard, "the visual imagery provided by the media can have a powerful impact on our attitudes, values, beliefs, and behaviors, since it can contribute meanings and associations entirely apart and of much greater significance" (kang, 1997, p. 980).

In view of these findings, Mathuvi et al. (2012) recommend that the selected books should be reviewed because they play a vital socializing role in shaping the education of the young generation according to which they may acquire "gender lenses" while evaluating and understanding the world around them (Mathuvi et al., 2012, p. 32).

\subsection{Review of the literature}

Past research relied heavily on the exploitation of the analytical techniques of content analysis to examine the content of textbooks. To counteract the potential adverse impact visual images may have on language learners, specialists in education have started to examine the pictorial content of school textbooks. 
Some of the earlier studies analyzing gender bias in the visual discourse of textbooks employed only the quantitative tools of content analysis. For this purpose, statistical techniques utilized for the analysis of pictures and visual illustrations cover such parameters as the frequency of appearance of both women and men (their visibility/ omission) in pictures, and/or the frequency count of their occupational roles (e.g. Weitzman et al., 1972; Sakita, 1995; Davoodi, 1999; Gooden and Gooden, 2001; Anderson et al., 2006).

Despite the view that the analysis of visual images using the quantitative techniques of content analysis is more indicative of the prevalence of sex bias in textbooks, the approach as such remains too superficial scratching only the surface of the problem and looking merely at the visible side of the iceberg.

Another stream of research focused on the qualitative side of content analysis in the investigation of visual images (e.g. Hogban and Waterman, 1997; Babii and Ansary, 2001; Bazler and Simons, 2006; Lee and Collins, 2008, 2010).

In their evaluation of the pictorial representation of women and men, Hogban and waterman (1997) focused more on the qualitative features of images. High status occupational roles are attributed to men far more often than to women. When a man is visually represented juxtaposed to a woman in a hospital, for instance, the usual biased pattern is that the male character is a doctor while the female acts merely as his assistant nurse. Men are commonly depicted taking more active leadership roles.

Relying on the same technique, Lee and Collins' (2008, 2010) studies have indicated almost the same results with male characters being showcased taking an active role and being more involved with sport activities than females.

Some studies have gone a bit further combining between the quantitative and qualitative techniques of content analysis in the examination of the visual representation of women and men in school textbooks (e.g. Amini and Birjandi, 2010; Levine and O' Sullivan, 2010).

Levine and O' Sullivan's (2010) study of the pictorial representation of women and men is very interesting in this regard. Basing their method on the quantitative and qualitative tools of content analysis, they analyzed how gender bias is projected through the images employed in an EFL textbook 'a Lot, Starter Book, Second Edition, 2008' used for Japanese university students. Their focus was on how the two sex groups are visually depicted in terms of (1) manner of dress, (2) involvement in sport, and (3) occupations.

The quantitative side of this study proves the predominance of male characters. Concerning the portrayal of women and men in sport activities, there are 18 images displaying males taking an active part as opposed to only two for females. The qualitative analysis of the photographic data demonstrates that males are seen in a plethora of occupations compared with females. When females are portrayed in occupations, though fewer, they "are illustrated in low social-status or stereotypical fields such as waitressing and selling flowers in a shop" (Levine and O' Sullivan, 2010, p. 37).

The implementation of the tools of content analysis for the study of pictures seems to be very intriguing and highly compelling as it has attempted to enhance and foster our understanding of the essential role of pictures in the exploration of sex stereotypes. 
However, although the analytical techniques of content analysis, be them quantitative and/or qualitative, present us with an informed interpretation of the insidious issue of sexism in the visual discourse of textbooks, a wide range of other discursive practices remain concealed at a more subliminal level.

Other more subtle and covert meanings of visual images, however, have been left unaccounted for. A more effective way to interrogate the implicit messages of these pictorial images has been endorsed by Giaschi (2000), Newfield (2011), Reza Adel and Enayat (2016), and Ziad and Ouahmiche (2019), among others. These authors seem to suggest the use of critical image analysis along with content analysis as a more enhanced method for the analysis of visual imagery.

In his study analyzing the positioning of women and men in the contents of visual images in contemporary ESL textbooks, Giaschi (2000) proposes a more powerful method he referred to as 'Critical Image Analysis' (henceforth, CIA). According to him, CIA is deemed as a visual adaptation of Critical Discourse Analysis (henceforth, CDA) which has the power to unveil the subliminal ideologies characterizing any use of visual imagery. The results of this study reveal several dimensions of gender stereotypes. In the visual positioning of women and men in the textbooks under study, two opposing binaries seem to prevail, namely "men as strong, active, in control, women as submissive, fashion-oriented, (and) controlled" (Giaschi, 2000, p. 41). He further contends that people are positioned in discourse as dominant / dominated, powerful / subordinate, superior / inferior, among others.

Relying on Giaschi's (2000) technique of critical image analysis in combination with content analysis, Levine and O' Sullivan's ( 2010) study of the visual data of EFL textbooks for Japanese university students, as outlined above, indicates more sex bias in discrimination of females. Female characters are portrayed in a childlike manner as they are seen as little girls dressed in school uniforms. The authors argue that this stereotypical portrayal of women seems to project "an image both childlike and juvenile. Females were overwhelmingly pictured as schoolgirls, in low status occupations, or as formulaic and stereotyped images of non-Japanese females" (Levine \& O' Sullivan, 2010, p.33).

Combining between the quantitative and qualitative techniques of content analysis alongside with critical image analysis, Tajeddin and Enayat (2010) examined the positioning of gender in the visual discourse of three ELT textbooks: New Headway, Top Notch, and Iran Language Institute English Textbooks. The results have demonstrated that men are given the privilege to be depicted visually as socially more powerful, more active and more competent. Women; by contrast, are presented as less active, socially powerless, and as sex objects. Women are also mostly presented in low-status roles, thus reinforcing their social inferiority. Men; on the other hand, are depicted more often in high-status occupations perpetuating their social superiority and their dominance.

Crucially important to review here is Newfield's (2011) most intriguing and thoughtprovoking article delineating a central shift in orientation from visual literacy to critical visual literacy. Critical visual literacy has been defined as an instructed viewing of visual images geared to promote:

"engagement with visual texts of all kinds and an understanding of how visual form constructs meaning. It advocated careful scrutiny of the elements 
that make up the image in order to enhance understanding and appreciation or to promote critical viewing skills" (Newfield, 2011, p 82).

The ultimate objective of critical visual literacy is to interrogate "the way society sees itself, sells itself, and in the way power in society is sought, maintained or challenged" (Ibid).

Reza Adel and Enayat (2016) examined the positioning of gender in the textual and visual discourses of four ESP textbooks published by Oxford University Press, namely Oxford English for Careers series including Commerce, Nursing, Technology, and Tourism. This study utilized almost the same analytical criteria used in Giaschi's (2000) critical image analysis. The results indicated that men are portrayed as the active participants of the images presented in more workplaces and more outdoor spheres which anchor them with more social superiority. Contrariwise, women are more often depicted in domestic areas such as the kitchen and performing household chores thereby heightening their powerlessness.

Being cognizant of the insidious effects of visual sexism in textbooks, Ziad and Ouahmiche (2019) analyzed in a more recent study two major parameters pertaining to sexism in the Algerian educational context. The study examined the visual representation of women and men in the contents of three EFL textbooks used in the Algerian secondary schools, and investigated at the same time EFL teachers' perceptions of this issue.

Utilizing the research tools of critical image analysis, Ziad and Ouahmiche's (2019) research indicated more instances of visual sexism in the sampled textbooks. Apart from very few exceptions of gender bias-free images, the overwhelming majority of the photographic data examined in this paper indicates more biased images in discrimination of female characters. Male characters are visually more represented, performing more social roles, and enjoying a more privileged status than their female partners.

\section{Methodology of Research}

\subsection{The sampled textbooks}

The present study undertakes the exploration of a body of visual data featuring female characters, male characters, or both in the visual discourse of Moroccan English as foreign language textbooks. Nine MEFL textbooks have been sampled to serve the particular purposes of this study. The selection of these textbooks was made on the basis of the criteria of purposive sampling. First, these textbooks have been selected for this study as they are still currently in use in all public educational institutions. Second, they have been written by Moroccan textbook writers, authorized and officially recommended by the Ministry of Education, and enjoy a wider usage among teachers all over Morocco. Third, as is the case with any textbook, these sampled textbooks have been examined, reviewed and recommended by the Bureau of the Ministry of Education textbook committee. The last criterion for the selection of these textbooks is based on the year of their publication which ranges between 2008 and 2010. This implies that they are expected to display a wellbalanced distribution and a fair portrayal of the two sex groups, as recommended by the gender bias-free directives documented in Sabir (2005). They represent almost 100 per cent of the whole range of textbooks currently used for classroom purposes.

The nine sampled textbooks cover the following levels: 
English Textbooks for Level 1:

(1) Focus (2008). Nadia Edition, Rabat.

English Textbooks for Level 2: Common Core Classes:

(2) Window on the World (2008). Rabat, Nadia Edition.

(3) Outlook (2010). Inter Graph, Rabat.

(4) Visa to the World (2010). Dar Nachr Almaarifa, Rabat.

English Textbooks for First Year Baccalaureate:

(5) Gateway to English.Book 1 (2010). Nadia Edition, Rabat.

(6) Ticket to English.Book 1(2009). Casa Blanca, DIO.El Hadita.

English Textbooks for Second Year Baccalaureate:

(7) Gateway to English. Book 2 (2010). Rabat, Nadia Edition.

(8) Ticket to English.Book 2 (2009). Casa Blanca, DIO.El Hadita.

(9) Insights into English (2008). Rabat, Nadia Edition.

The data upon which this study is based is drawn from a collection of visual images featuring male characters alone, female characters alone, and male and female characters either in pairs or in groups. Sampling procedures for qualitative research entail, as Maxwel (2005) recommends, 'criteria-based selection' or 'purposive sampling' as a common practice of non-probability sampling. As such, a total of 306 images featuring the activities and the occupational roles of women, men, or both were collected for the analysis of this study. Pictorial images of other subjects including houses, animals, cartoons, and people of unspecified sex were excluded from the data.

\subsection{Procedures of analysis}

The analysis of our photographic corpus hinges heavily on a combination of the techniques of qualitative content analysis and Giaschi (2000) and Newfied's (2011) new concept of CIA. Such a bi-modal investigation is undertaken to account for the explicit as well as the implicit messages about women and men projected through the visual discourse of these textbooks.

The parameters along which visual images are analyzed have been designed on the basis of three questions set forth in Giaschi's (2000) critical image analysis: (1) what is the activity of the image? (2) Who is active or the protagonist in the image? and (3) who is passive or the receiver in the image? (Giaschi, 2000, p.37). These three questions have been condensed into one criterion referred to here as 'activity versus passivity'.

This criterion accounts for the activities male and female characters are involved in. The agent or the doer of the activity is perceived by Giaschi (Ibid) as 'the protagonist' in the picture. A passive participant, on the other hand, is the one who is subject to the entire activity either acting as a receiver of the action, or as 'an observer of what is going on', or taking merely a decorative role (Acevido et al., 2006). The positioning of the two sex groups in the pictures will explain and determine who is active and who is passive.

Kress and Van leeuwen (2006) and Van Leeuwen (2008) make almost a similar analysis referring to 'social actors'. This suggests that the participants of social practices depicted through discourse may have 'agency' to exercise more influential roles performing 
an activity, or occupying a specific social position. Social actors can be accounted for "in terms of (the participants') personal, kinship, or work relations to each other" (Van Leeuwen, 2008, p. 43).

It is worth noting that out of the total number of pictures of our corpus, a sample of images will figure inside the text for more clarification. All of these pictures have been chosen based on how well they fit into each of the levels of analyses described above. These visual depictions are incorporated in this paper to give clear evidence to the arguments discussed in this visual analysis. As a matter of fact, a sample of 31 photographic materials which constitutes an important part of the bulk of the visual data of this study is presented along with its corresponding sources in the text. The images figure following the chronological order of the thematic aspects of this paper.

\section{The Results}

This section sets out to present and discuss the findings which crop up from the analysis of the visual data using a bi-modal approach. They are arranged following certain themes observed to be of a recurrent frequency in the pictorial discourse of the sampled textbooks.

\subsection{Gender bias in the visual portrayal of women and men's social activities}

A prevailing feature specific to the visual discourse of MEFL textbooks relates to the type of activities assigned to women and men. As with the analysis of the textual discourse of the selected textbooks discussed and reviewed in a different paper (Benattabou, 2014), two divergent trends seem to emerge from the analysis of their pictorial images. Male characters are far more often seen on display featuring the role of the protagonist taking a vital role in the frame of pictures.

Picture $\mathrm{N}^{\circ} 1$ in Visa (p.27), as a case in point, seems to be more revealing in this regard. There is a tendency among male characters to outstrip females in the visual discourse of the sampled textbooks. The picture places more emphasis on the explanation of ten activities. Surprisingly enough, nine out of ten (90\%) of these visual images displaying a wide range of activities are all male-centered. The only exception is one picture displaying a woman drawing artistic pictures representing merely $10 \%$ of the whole group of images.

Picture $\mathrm{N}^{\circ} 1$ :

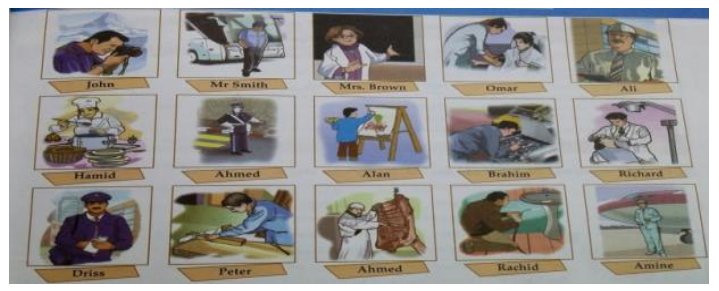

In view of the social activities ascribed to men, there is an inclination to see male characters in a host of activities playing multiple roles. They are visually depicted undertaking such professions as a pilot, a dentist, an engineer, a doctor, a bus driver, among others. They are also seen playing the role of authority officials, delivering public speaking presentations, and taking a prominent role in politics ( $\mathrm{N}^{\circ} 2$, Insights, p. 105). 


\section{Picture $\mathrm{N}^{\circ} 2$}

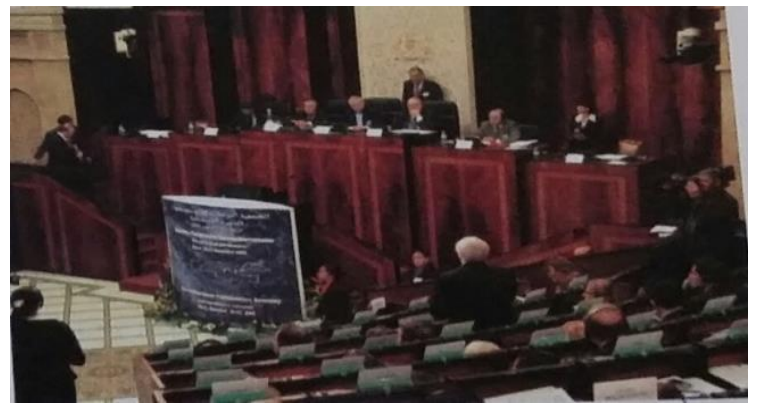

Conversely, the activities assigned to women are invariably anchored to the household chores cooking, washing the dishes, preparing meals in the kitchen and being dressed in an apron, as a common token of domestic life ( $\mathrm{N}^{\circ} 3$ in Ticket 2, p. 79, and $\mathrm{N}^{\circ} 4$ in Visa, p.42). They are also represented as mothers and housewives whose ultimate preoccupation is to take care of their babies and their children ( $\mathrm{N}^{\circ} 5$, Ticket 2, p. 79), or as nurses taking care of other people's health (Visa, p.76). They are further cast in the world of shopping ( $\mathrm{N}^{\circ} 6$ in Window, p. 72), or selling menial goods in a traditional food market $\left(\mathrm{N}^{\circ} 7\right.$, Focus, p. 118).

Picture $\mathrm{N}^{\circ} 3$ :

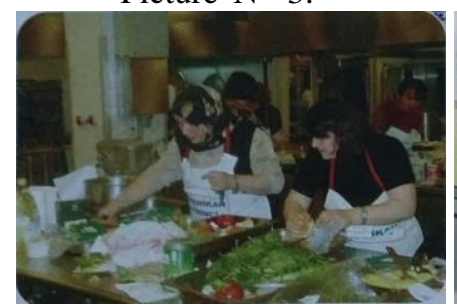

Picture $\mathrm{N}^{\circ}$ 4:

Picture $\mathrm{N}^{\circ} 5$

Picture $N^{\circ}$ 6:
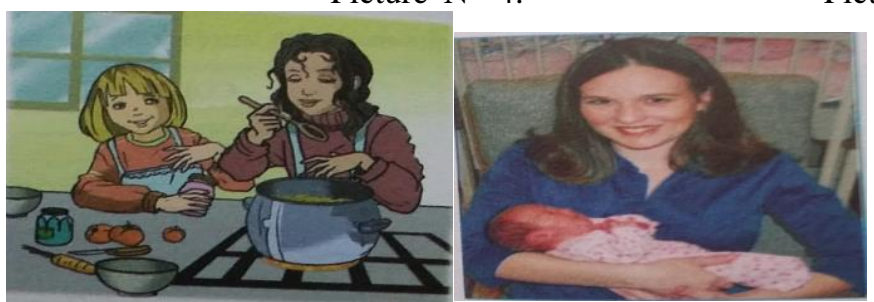

Picture $N^{\circ} 7$ :
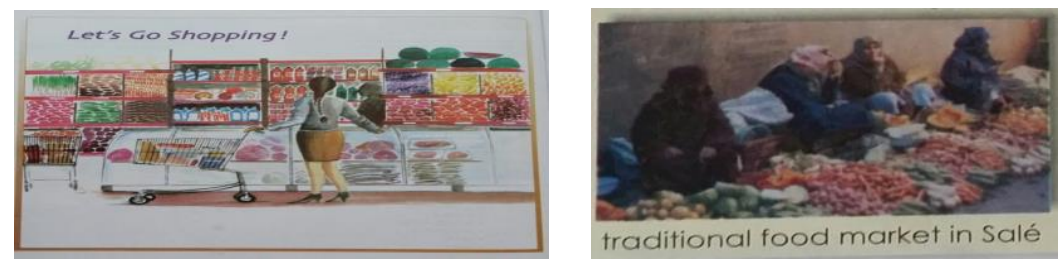

More stereotypical depictions are observed when women and men are portrayed juxtaposed to one another. There is a general tendency to depict women being under the mercy of men. Male characters are portrayed as protagonists grabbing females' hands, wrapping their body, or stretching their hands to help them.

In picture $\mathrm{N}^{\circ} 8$ (Focus, p.65), as a case in point, a woman is depicted prostrating and kneeling down as a form of reverence in front of the man stretching her hand towards him as if seeking his mercy or protection. Similarly, in picture $\mathrm{N}^{\circ} 9$ (Ticket 1, p.138), a male character is visually showcased rescuing a woman from danger. The man is put in the position of a savior, being in focus and looking down over the girl stretching his arm to grasp firmly her hand as a gesture to rescue her life. Masculinity is seen in terms of control and power over the powerless (in this case, the girl and by extension women). Masculinity 
could also be conveyed through the man's daring decision taking all the risks to save the girl. The man is fore-grounded while the girl is shown from the back, presumably being stripped symbolically from her own personality and identity.

Picture $N^{\circ} 8$ :

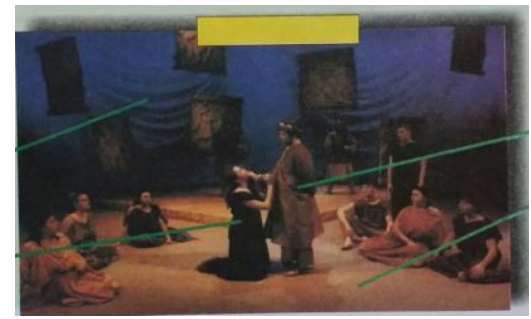

\section{Picture $N^{\circ} 9$}

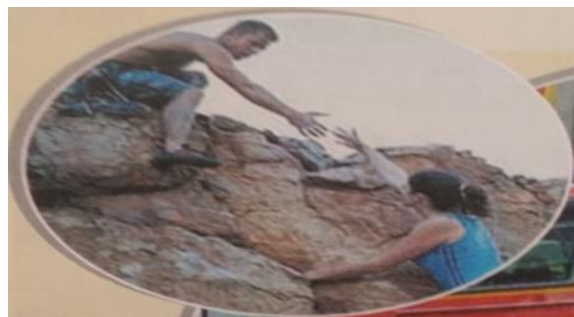

More interesting perhaps is picture $\mathrm{N}^{\circ} 10$ (Ticket 2, p. 94) displaying an annual competition where men tend to carry women to expose their prowess and competitiveness. The woman is seen being carried on a man's back as an object or a commodity to be taken away. The man is in focus taking a larger space of the image and being active while the girl is shown as passive, inactive and inept. One implication here is that women are perhaps valueless and should often be taken charge of.

Picture $N^{\circ} 10$ :

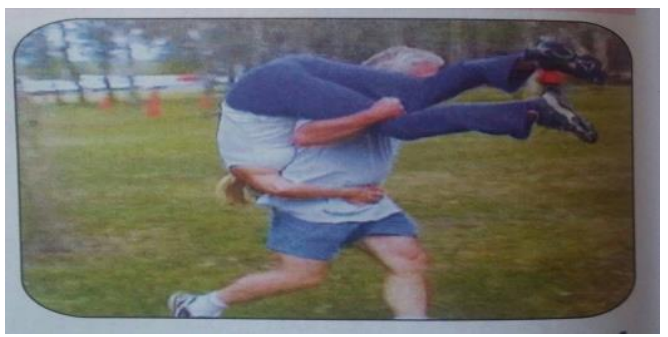

Although the visual discourse of MEFL textbooks seems to be more male-oriented particularly with respect to the activities associated with women and men, there are some images of women working on computers, delivering presentations and playing the role of chemists (see picture $\mathrm{N}^{\circ} 11$ in Insights, p.45 and another one in the same textbook p.46).

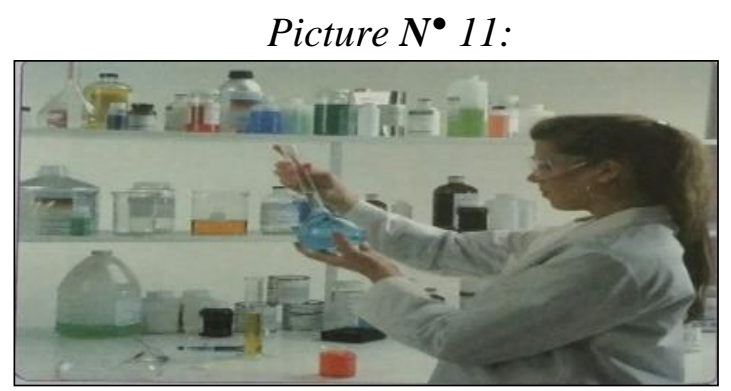

Subsequent to the portrayal of these two female chemists still in the process of experimentation, the male chemist in the third picture in Insights $\left(\mathrm{N}^{\circ} 12, \mathrm{p} .47\right)$ comes to the fore and in full size, standing in firm control of the situation displaying in pride a new research discovery ( a breakthrough). Although these visual images are presented in three separate pages (Insights, p.45, p.46, p.47), they are interrelated as they are subsumed under the same unit devoted to the description of scientific experiments. 


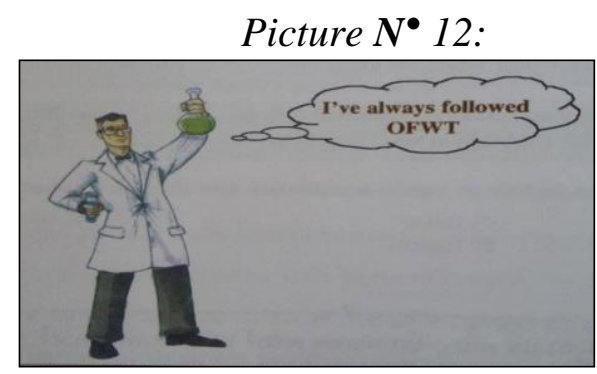

Another visual posture recurrent in the textbooks under scrutiny, and which perpetuates women's so-called passivity is their portrayal as mere observers. Unlike women, male characters are presented being active in the social scene of their corresponding countries. They are visually portrayed volunteering and taking a dynamic participation in the ongoing progress of their social context.

Image $\mathrm{N}^{\circ} 13$ (Gateway 2, p. 45), in specific, is unfairly emphasizing not only man's active and dynamic role, but is focusing at the same time on women's passivity, inactiveness, and absent-mindedness. Women are not depicted as active agents as their male peers with regard to volunteering, risk-taking, and social availability to collaborate.

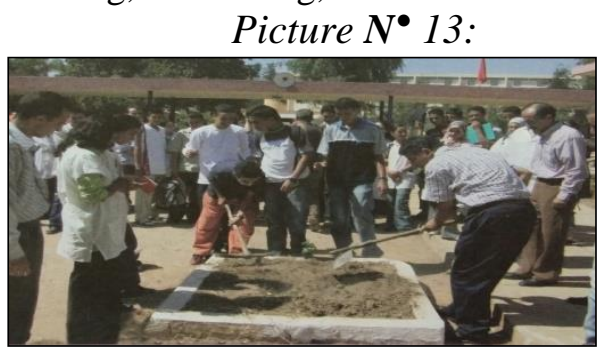

While men are given the exclusive privilege to undertake some daring actions like volunteering to help and taking the initiative to rebuild some places as a form of civic contribution, women are utterly marginalized as they are repeatedly depicted merely observing and watching what is going on around them. They seem to be off place playing the simple role of witnesses or on-lookers. For additional evidence of this biasness, see an almost identical image in Gateway 2, (p. 152).

On a somewhat similar note, in the medical field men are shown as doctors while females play the role of nurses or assistants. In image $\mathrm{N}^{\circ} 14$ in Outlook (p. 68), the male doctor is depicted examining a patient and the female nurse is standing nearby merely as an observer looking straight into his eyes waiting for his instructions.

Picture $N^{\circ} 14$ :

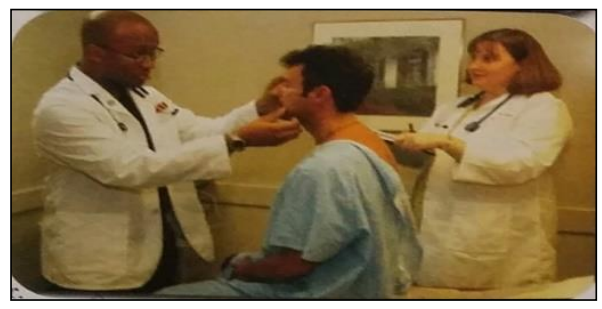

More revealing, perhaps, of this imbalance is the pictorial representation of people in picture $\mathrm{N}^{\circ} 15$ (Gateway 1, p. 109) displaying men rioting and protesting in anger to express their concern for a positive political change in their countries. Although women have been known through history to have participated substantially in the prolific and 
historic events of their societies, they have almost all the time been thoroughly marginalized and excluded from all such scenes.

\section{Picture $N^{\circ} 15$ :}

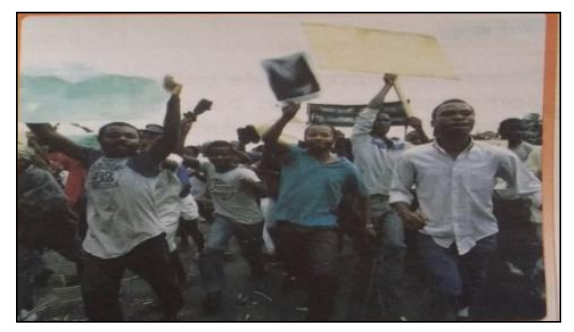

Of particular concern here is image $\mathrm{N}^{\circ} 16$ (Insights, p. 78) depicting the closing graduation ceremony where students may express their happiness of the event. Through foregrounding, the attention of the viewer is drawn first to a more dynamic male student dressed in a gown, and his head covered by a graduation hat raising both arms up in the air holding a certificate of success in his hands in celebration of the special occasion.

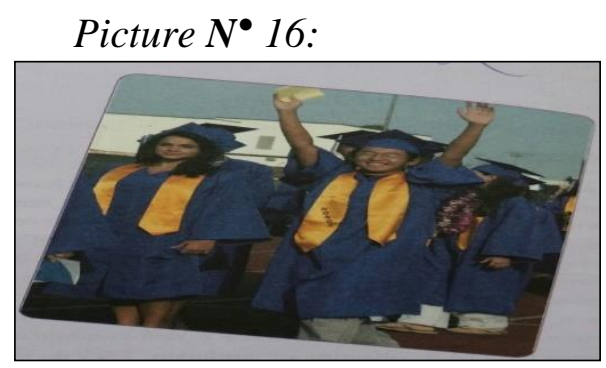

Contrariwise, the female classmate in his company, dressed in the same way, seems to be passive, docile and not reacting actively in the same manner. This visual juxtaposition may serve the hidden agenda of accentuating male dominance and excellence. The corollary of this is that women have been silenced and excluded altogether from any active participation in these social roles. They are reminded to stay as passive witnesses in a perpetual position of 'wait and see'.

Part of what is unsaid in this picture is that the graduate girl in the boy's company, though entitled with the same qualifications, is portrayed almost standstill, and does not display through body language any sense of self-pride or strong determination to pursue her long-lasting journey of success. She seems unconcerned of what is going on as though celebrating one's success in life is a male prerogative right par excellence. The boy is depicted jumping in the air symbolically suggestive of his optimism and dynamism. He is visually prioritized and fore-grounded leaving no space for the girl to express her joyfulness.

The implicit message conveyed here is that women have no say in such positions, and are perhaps warned against the potential risks they may run if ever they may venture to step beyond the thresholds of the household context. The stakes may surely be very high as constant screening of these pictorial representations will indoctrinate female language learners into taking everything as normal and at face value. Ultimately, women may ideologically be compelled to succumb at a subliminal level to all such cultural misconceptions.

Another more pervasive dimension of these textbooks is to position women in more vulnerable settings, exacerbating thereby their victimization and their disempowerment. 
Women have been subject to a process of victimization as their personal characteristics are usually anchored to such themes as poverty, illiteracy, illnesses, and being distressingly in dire need of man's protection and help.

Picture $\mathrm{N}^{\circ} 17$ in Gateway 1 (p. 29), for instance, displays a group of older women dressed in very traditional clothes attending a course in a classroom. The text which accompanies this picture sends a message that these women are illiterate, and therefore are still in dire need of help, guidance and supervision. The way they are positioned sitting quietly suggests they are passive recipients forced to enter schools to fight illiteracy even in their adult life.

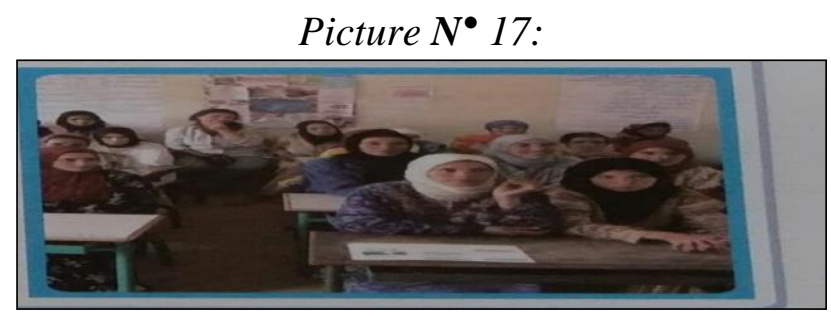

Whenever the issue of illiteracy is raised, it is always the case that women dressed in traditional clothes are presented. Almost the same image has been found in other textbooks echoing the same biased theme (see Ticket 2, p. 38 and p. 43). It is very surprising that male characters are exempt from all such biased pressures as if the problem of illiteracy is the exclusive concern of only women but not men.

Such an attitude seems to distract our attention from looking at women as active agents contributing to the progress of their social contexts. This is consonant with the findings drawn from studies in clinical psychology reviewed in Harris and Lighter (1980). This trend of research has given more evidence that when psychology textbooks set out to illustrate the psychological disorders or abnormalities in their chapters, they seem to be more biased. It is usually female characters who have been blatantly exploited to elucidate the cases understudy. According to this research, women seem to predominate in "case studies and prototypic examples of psychological disorders", and that "psychotherapy especially when accompanied by anxiety or distress is a typically female attribute" (Ibid, p. 399).

\subsection{Women and men in sport activities}

Consistent patterns of results emphasizing the discrepancy in the social activities of women and men in the visual discourse of these textbooks pertain to the sport activities they are involved in. These activities are disproportionately biased towards male characters being visually showcased as the norm.

The pattern of over representing male characters in an array of sport activities is more common in MEFL textbooks. With the exception of Ticket 1, all the sampled textbooks portray football, as a case in point, as the exclusive realm of man. There are several pictures which display this tendency among male characters to be heavily involved in the world of football. The predominance of men in this male-centered activity has been crowned with the portrayal of the Moroccan National team of football in image $\mathrm{N}^{\circ} 18$ (Visa, p. 59), and the Kenyan National team in (Outlook, p. 80). 


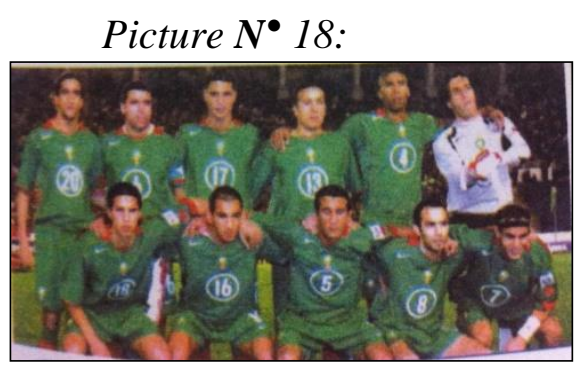

Additionally, male characters seem to figure in a number of sport competitions. The predominant trend of these activities is that they warrant strength, tough muscles, endurance and perseverance. In addition to football and basketball, men are also portrayed far more often in pictorial images featuring man-oriented sports like wrestling, cycling, playing baseball and swimming or running in tough competitions (See image $\mathrm{N}^{\circ} 19$ in Focus, p.72). Similar visual images have been used to depict men displaying their prowess, masculinity and high stamina, namely in very tough athletic competitions (Ticket 1, p.37, and p. 43), or standing upright displaying their readiness to fight in Karate (Outlook, p. 89).

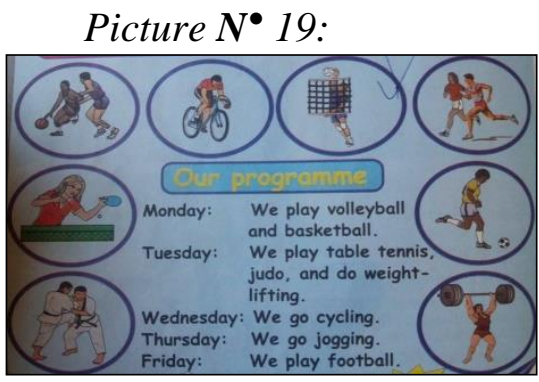

There is also a tendency among men to be over represented being active in a plethora of activities like climbing, fishing and hunting. They are further visually presented displaying a supernatural power being venturesome, daring and enjoying an exceptional prowess like a Spiderman (Focus, p. 63, N ${ }^{\circ} 20$ ), and a gladiator (Gateway 2, p. 126, N²1). These sport activities are traditionally associated with men as they warrant strong endurance, courage and a robust physical fitness.
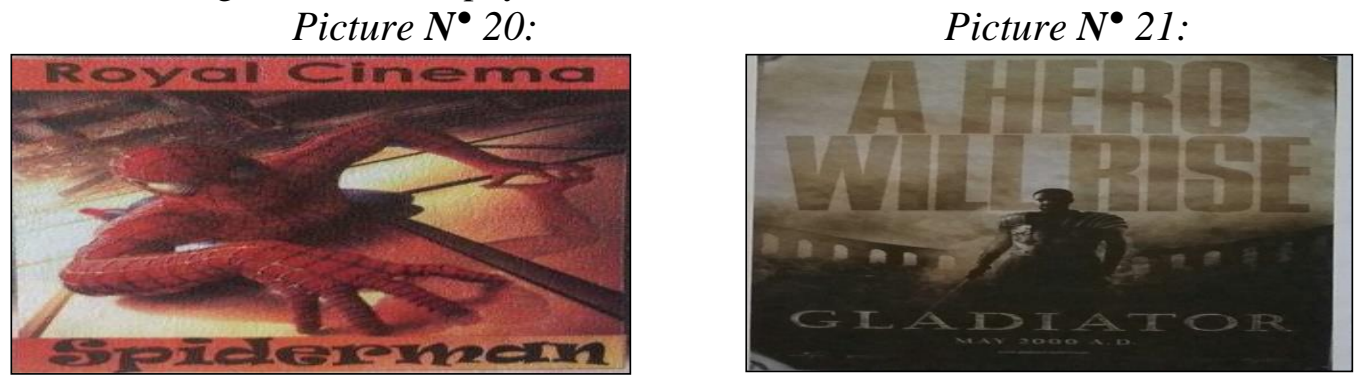

Female characters, by contrast, are stereotypically underrepresented as they figure merely in fewer sport activities. Their visual portrayal in such activities is very limited and restricted both in quantity and quality. They are depicted in merely 15 pictures (26.78\%) as compared to men being represented in 41 pictures with a frequency of distribution averaging a lion's share (73.22\%).

When they are pictorially focused on, adult and young women are anchored to such 'feminine' sports like gymnastics, tennis, and volley-ball which are traditionally deemed as female specific areas of interest. Female characters seem to figure only in these sport 
activities which require less vigor and less competitiveness (Focus, p.68 and p.72). They are also observed to occupy such 'infantilized' sport activities like playing with ropes, skating or playing tennis table (See image $\mathrm{N}^{\circ} 22$, Gateway 1, p.55).

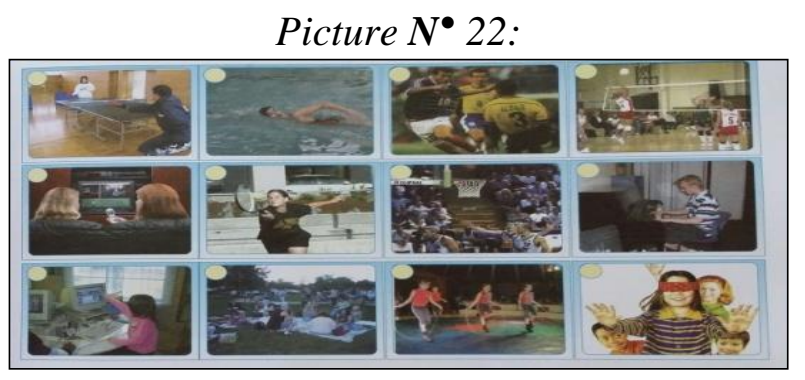

What do these sport activities assigned to women have in common is that they do not involve any physical tough contacts with others. This is of course in tune with such traditional assumptions which continue to see women are weak, vulnerable, less competitive, sensitive, fragile, and less venturesome.

\subsection{Ghettoization' of women}

Another prevailing theme of more occurrences in MEFL textbooks geared precisely to Baccalaureate students is entitled "Women and Power". This separate unit has been introduced in three textbooks namely Insights, Gateway 2, and Ticket 2 to give due recognition to women issues and women in more powerful positions.

Insights, for instance, has incorporated this unit to present some famous women. Picture $\mathrm{N}^{\circ} 23$ (p.63) depicts five separate images of women including Nawal El Moutawakil described as "the UNICEF goodwill ambassador", Fatima Mernissi as "a sociologist", Farida Belyazid as "a film maker", Malika El Fassi as "a nationalist", and Meryem Chahid as "an astronomer".

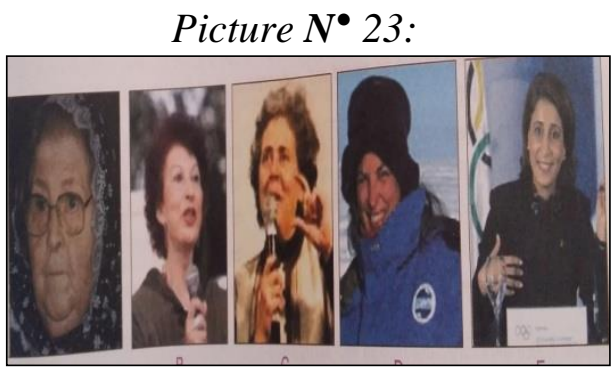

Surprisingly enough, the list of famous men visually presented in the same textbook (Insights, p. 60, $\mathrm{N}^{\circ} 24$ ) portrays six more prominent figures but with completely different captions. The wording in these captions is more biased favoring men as there is an overuse of adjectives reinforcing male supremacy: Albert Einstein presented to the reader as a "Nobel Prize Winner"; Louis Pasteur as "best known for remarkable breakthrough in microbiology"; Ibn Khaldoun as "a brilliant and prolific scientist"; Thomas Edison as "one of the most prolific inventors in history"; Alexander Graham Bell as having "invented the telephone at the age of 29"; and Bill Gates as receiving "about 100 e-mails a day". There is indeed strong evidence to argue that MEFL textbooks are highly stereotypical in their visual depictions in stark discrimination against women. 


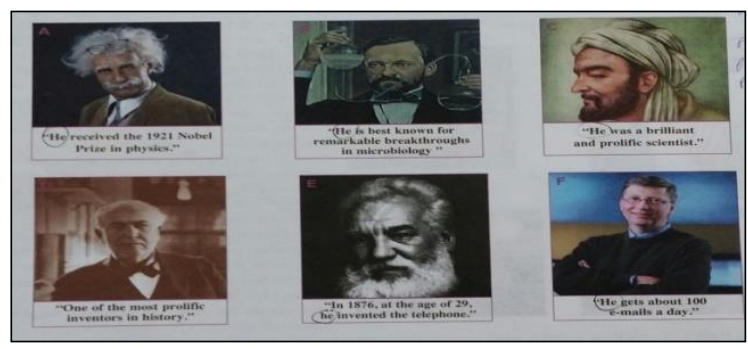

In a like manner, in Ticket 2 there are merely four visual depictions of famous women, notably Margaret Thatcher, Angela Doraka Merkel, Nawal El-Moutawakil, and Shireen Abbadi (p. 66-67, $\mathrm{N}^{\circ}$ 25). Subsequent to this, when Fatima Mernissi (p. 74) and Leila Abouzeid (p. 76) have been presented there is scant information about them.

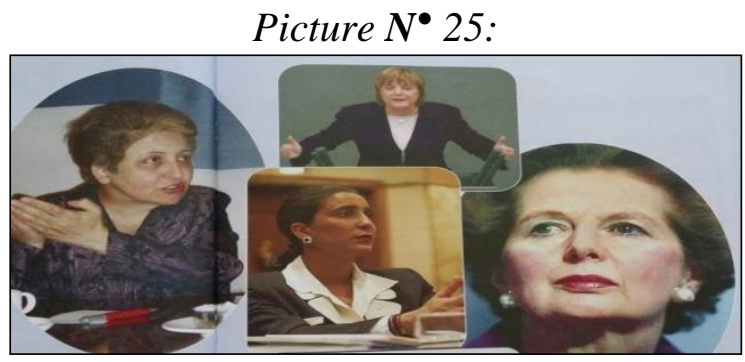

Similar patterns of results have been echoed in the visual discourse of the same unit "Women and Power" in Gateway 2. Reference has been made to six women figures particularly Meryem Chahid "famous Moroccan astronomer", Leila Abouzeid "first Moroccan writer of literature to be translated into English", Chandkira Kumeratunga "president of Sri Lanka", Ellen Johanson Sirleaf "United Nations high commissioner for Human Rights, and former president of Ireland", and Angela Doraka Merkel "Chancellor of Germany and the most powerful woman in the world 2006" (Gateway 2, p. 49).

While there is a profusion of positive superlatives to make the pictures of famous men more prominent and very distinguished, the only superlative form used here is the one describing Angela Merkel: "the most powerful woman in the world 2006".

It is very interesting to note here that for MEFL textbooks to align with Moroccan writers' non-sexist guidelines (Sabir, 2005), these textbooks for Baccalaureate students (Gateway2, Ticket 2, and Insights 2) have all incorporated this unit reserved exclusively for women issues. They seem they have begun to recognize the increasing importance in incorporating women as an integral part of mainstream population. Through this unit, female language learners are given at least a chance to rejoice reading with pride about women's remarkable contributors in all walks of life: social, economic, political and scientific. Their accomplishments have been described as being vital for the development of any society.

This is, however, a bitter pill coated with a sugary substance. First, rather than being referred to as often as men throughout the whole discourses of the textbooks, the contributions of women in this unit have been singled out as if they were not a basic composite of mainstream population.

Worse than this, the rate of distribution of women in the textbooks remains disproportionately very low. The unit "Women and Power" in Insights, as a case in point, subsumes 142 female nouns and pronouns, which represents $72.82 \%$ of the total number of female target words in the whole content of this unit. This implies that the remaining 
smaller portion (27.18\%) is allotted to the other 9 units representing on the whole a very low percentage of only 3,02\% of female representations per unit compared to men.

Additionally important, although the units "Women and Power" have been integrated as separate units within the contents of these three textbooks, this process has repeatedly been criticized for creating the problem of women's 'ghettoization'. By the same token, women have been singled out and clustered in a separate unit as if they were not part and parcel of their corresponding societies.

The bi-modal analysis undertaken so far examining the discourses of these textbooks, gives us the impression that their designers have probably inserted this unit just to impart the false and misleading conception that they are aware of the problem of sex stereotypes. Yet, their attempts to highlight women in one unique unit may seem to be more of a curse than a bliss.

\subsection{Women and men's contributions to the progress of humanity}

An additional hidden ideology promulgated through the visual discourse of MEFL textbooks concerns the depiction of people who contributed to the progress of humanity. There are myriad instances of visual images which attest to this trend. There seems to be a risk that Moroccan students of EFL textbooks will be brainwashed to believe that history and the evolution of civilizations in all walks of life have seen considerable headways thanks to the exclusive contributions of men. A wide range of visual images have been, wittingly or not, deployed to serve this purpose. This may surely cultivate among learners more stereotypical visions regarding their appropriate gender roles, and which may by implication widen the gap between the two sex groups.

Picture $\mathrm{N}^{\circ} 26$ in (Gateway 1 p. 68), for instance, displays the commemoration of the historic victory of Morocco in its liberation of the so-called Spanish borders of the Moroccan Sahara. The image is very symbolic of the biased discourse of the sampled textbooks as it depicts a group of male characters, to the exclusion of women, trespassing in pride the frontiers and being at the front lines stretching their hands up in the air as an expression of their triumph. They are also visually portrayed holding in victory the Moroccan flags, the pictures of King Hassan II, and the holy Koran.

Picture $\mathrm{N}^{\circ}$ 26:

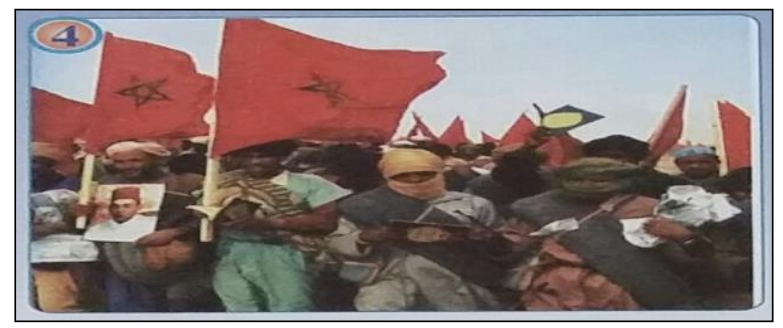

Although women participated substantially in this prolific and historic event, they have been thoroughly marginalized and excluded from the visual scenes celebrating its liberation. Men; however, are fore-grounded and prioritized taking a dominant role in the whole frame of this picture. Such a finding is in tune with Sadiqi's (2008 b, p. 166) forceful argument that "women's roles are either ignored or made secondary to men's, constructing thus Moroccan women's subordination and supporting patriarchy through centuries" (2008 b, p. 166). 
Other pictorial images have been deployed to point out that history and the progress of humanity is man-made. In picture $\mathrm{N}^{\circ} 27$ in Gateway 1 (p.75), for example, there are six separate pictures of famous figures enjoying a wide recognition at the international level. Women have been completely barred from the list which encompasses Galileo Galilei, Albert Einstein, Thomas Edison, Isaac Newton, Louis Braille and Tales Bell. Although there is truth in the historical facts of these male scholars, there is no reference whatsoever to any female scientist.

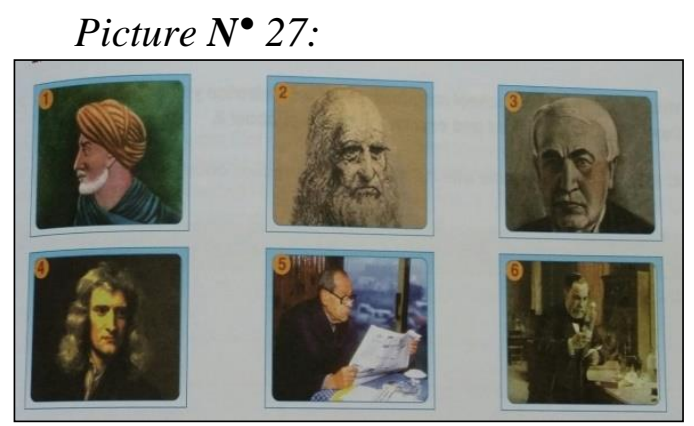

The textbook designers of Window seem more inclined to take essentially the same stance. There are five pictures glorifying and extolling only male figures namely Pablo Picasso, Van Gogh, Steven Spielberg, James Cameron and "Matrix" (Window, p. 106).

Following the same line of reasoning, in picture $\mathrm{N}^{\circ} 28$ presented in Window (p. 17), there are seven images of well-recognized persons including Najib Mahfoud, William Shakespeare, Tom Cruise, Jacques Chirac, Chapman, Albert Einstein and Pablo Picasso. Supplemented to these, there are three images of female personalities particularly Marlin Monroe, Hilary Clinton and Winslet representing merely 37.5\% as opposed to $62.5 \%$ for males.

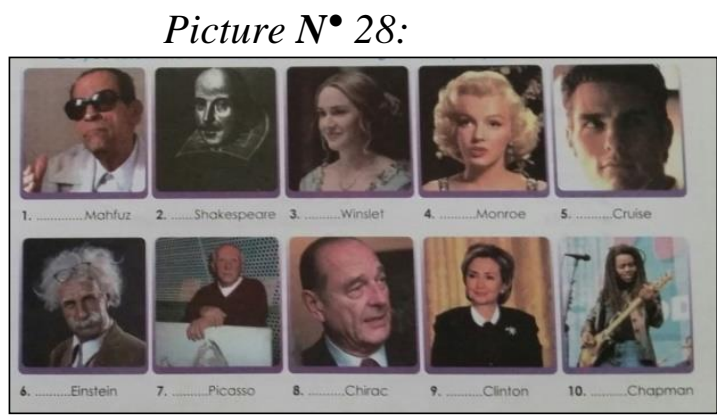

As reviewed earlier, Insights displays also the pictorial representation of six scientists enjoying a worldwide recognition namely Albert Einstein, Louis Pasteur, Ibn Khaldoun, Thomas Edison, Alexander Graham Bell, and Bill Gates (Insights, p. 60). To the exclusion of women, these male scientists have been incorporated in the text disseminating one single message that the world of scientific discoveries is man-made.

Likewise, it is observed in the same textbook (Insights, p.28, image $\mathrm{N}^{\circ} 29$ ) that there are four visual images of such prominent figures as Abdellah Laroui, Edward Said, René Descartes and Bernard Arthur Russel.

Picture $\boldsymbol{N}^{\circ} 29$ : 


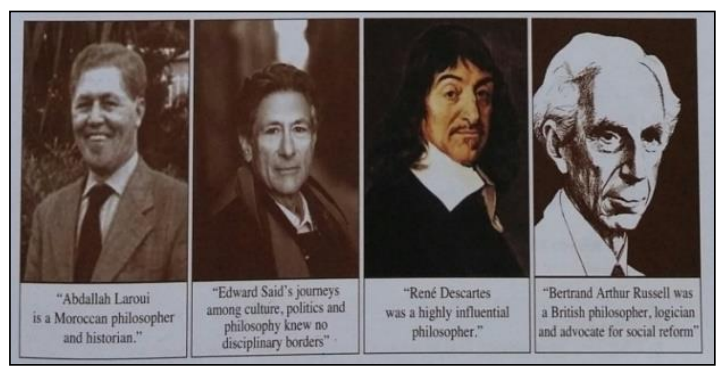

Official documents embodied through stamps and money notes have also been presented as male dominant. Ibn Khaldoun is visually depicted within the frame of the Moroccan stamp (see Gateway 1, p. 146, image $\mathrm{N}^{\circ} 30$ ). Similarly, in image $\mathrm{N}^{\circ} 31$ (Visa , p. 118 ), there are five bank notes four of them $(80 \%)$ are male-centered, while only one single note has been reserved to a female character representing a very tiny minority with a percentage averaging merely (20\%).

Picture $\mathrm{N}^{\circ} 30$ :
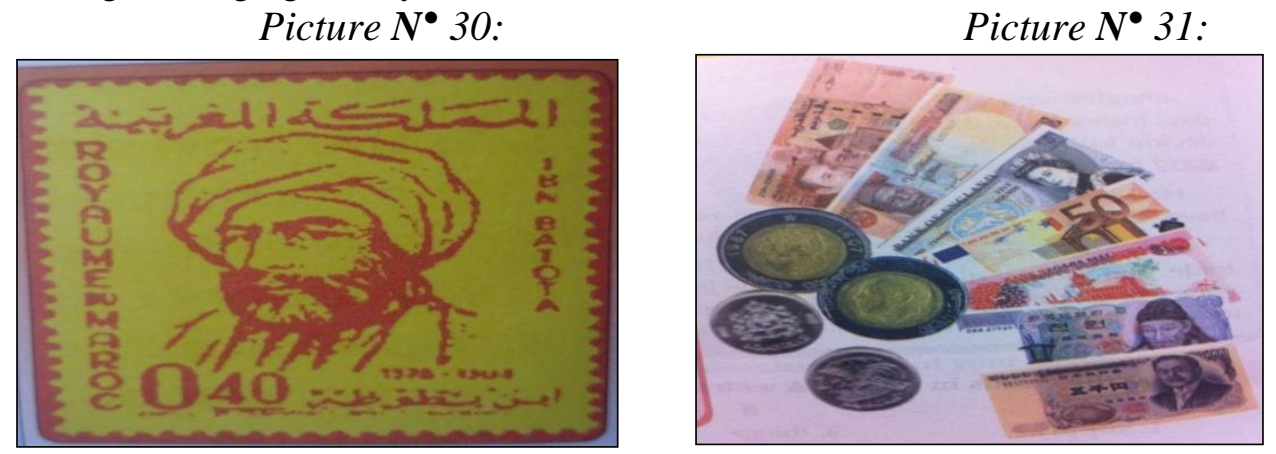

In view of this, there might perhaps be a risk that Moroccan students of EFL textbooks may be ideologically indoctrinated to understand that the giant strides undertaken at a worldwide level have been accomplished thanks to the influential contributions of men to the exclusion of women. Students are more likely left to feel that women have no share whatsoever in all of these so-called man-made prolific advancements.

\section{Discussion of the results}

The findings of this research show very convincingly that Moroccan EFL textbooks are replete with myriad instances of sex-stereotyping. This bi-modal analysis of the visual discourse of the sampled textbooks has tried to highlight some cases of gender imbalances which continue to shape in a subtle way the pictorial representation of the two sex groups. This lends more credence and substantiates to a greater extent our textual analysis of the same issue in the same sampled textbooks reviewed in a different paper (Benattabou, 2014).

The overall results of this study seem to indicate that there is also a paradoxical correlation in that the visual representation of female characters in domestic settings is disproportionately very high, while that of their portrayal with respect to the workforce is rendered almost invisible particularly when it is related to managerial roles. By contrast, a relatively smaller percentage of these illustrations feature male characters in domestic settings; they seem however to be more predominant taking the lion's share of almost all leadership roles. 
Another more biased description prevalent in the visual discourse of these textbooks, and which proves that the sampled textbooks have been designed through male lenses, is the exclusion of women from history. The progress humanity has gone through, and the remarkable contributions accomplished so far throughout the history of all nations at a worldwide level are invariably referred to as man-made. In Visa, for example, seven prominent scholars who have marked history at different levels are portrayed visually, all of whom are men (Visa, p. 15). Also in the same page, six famous stars are identified in pictures, only one of them is a woman, yielding on the whole a male to female ratio of 12:1.(Visa: 15).This implies that for every twelve male portrayals there is only one for females. This exclusion of women from history seems to resonate well with Sadker and Sadker (2004) and Omran's (2006) findings.

Despite women's achievements and collaborations, they are still subject to discrimination, segregation and marginalization in school textbooks. According to Porreca (1984) and Sadker and Sadker (1984), when the contributions and accomplishments of famous women have been dismissed and excluded through discourse, this may perhaps send the implicit message that they have either been absent from the political scene, or that their achievements are not worth knowing or not important enough to be incorporated.

Male characters have also been shown to outweigh females both in quantity and quality. They are often portrayed as numerically larger and connected with high-status jobs. Mr. J. Cook is a teacher, J. Kennedy is an engineer and N. Farhat is a journalist, all of whom are males. Surprisingly enough, in complete harmony with their traditional sex roles, females are depicted in the same page only as secretaries or nurses (Ticket1, p. 26).

No matter how colossal and giant women's efforts and strides are, they have customarily been, according to the lenses of these visual portrayals, marginalized, silenced, and miniaturized. They are shown as if they were reluctant and undecided to enter new occupational roles, or as if obstructed from growing up professionally.

The social strains to remain forever at home are not as great for men as for women. This is strongly evidenced by the excessive depiction of women in home-oriented clothing associated with the apron, which is suggestive of domestic activities like cooking, cleaning, or doing the laundry (See images $\mathrm{N}^{\circ} 3$ in Ticket 2, p. 79 and $\mathrm{N}^{\circ} 4$ in Visa, p.42). This is congruent with the patriarchal mindset of the Moroccan society which dictates what should or should not be appropriate for men and women. Sadiqi (2008 b) arguably observes in this connection that:

"Moroccan culture is of a type that strongly constrains the behavior of men and women. The strength of this control comes from the fact that it is channeled through powerful cultural components that closely regulate the lives of Moroccan men and women through the establishment of powerful social institutions"(2008 b, p. 166).

The danger of these images is that they may exude the false misconception that women are socially and culturally expected to have no other future occupational horizons as important as being merely married, or becoming an ideal superwoman who can do it all at once: a cook, a nutritionist, a tutor, and a good-looking housewife. 
The findings of this investigation seem to suggest that patriarchal attitudes and social expectations are invariably projected through the visual discourse of these textbooks, with male characters figuring significantly far more often in most of the occupational roles in the public and private sectors. This may also imply that past traditions which perpetuate a binary and a dualistic vision of female and male gender roles remains relatively stable.

Cases of female models in leadership roles are very limited, and are reduced to a strict minimum. Women continue to be seen only as nurses, secretaries, receptionists, employers and in most cases male subordinates. This visually biased portrayal of women has also been reinforced through the textual discourse and the captions which accompany the aforementioned visual images (See Benattabou, 2015).

Even in those very restricted social roles, female characters are ridiculed (e.g. the mother admitting that it is her fault when the kids get sick:

“Mother: Quick Jimmy! Get help. In fact, it's all my fault. I mustn’t leave Rim by herself and I mustn't leave medicine around" (Outlook, p.72).

Similarly, women's accomplishments are trivialized, and they are far more often associated with evil and devilish acts. Margaret Thatcher, for instance, is seen as "the longest serving British Prime Minister" and "the first woman to lead a major political party in UK" (Ticket 2, p. 72).

The problem with Margaret Thatcher's bio-data is that she has been stripped from her iconic name known in the history of the United Kingdom as 'the Iron lady'. Instead, much focus has been laid on her pitfalls namely that:

"Her first two years in office were not easy" and "one great difficulty during her time in office was the issue of Europe. Her long serving foreign secretary, Sir Geoffrey Howe resigned in November in 1990 in protest at Thatcher's attitude to Europe. His resignation speech started events which led to Thatcher's downfall later that month" (Ticket 2, p.72).

The issue in question with this seemingly intentional focus on her political failure may distract the reader from looking at her as an outstanding female leader who has succeeded to rule and govern during her era.

Such stereotypical ideologies are suggestive of the patriarchal attitudes and beliefs of the past as the old saying goes: "it's a sad house where the hen crows louder than the cock". This English expression blatantly underestimates the role of women in managerial roles, and seems to conjure up a pessimistic vision about their contribution as potential leaders.

'Cherchez la femme' (literally means 'look for the woman', in English) is another old saying of the French culture which, irrespective of whoever is responsible for the act of offence or misdeeds, tends to incriminate women by default.

The same stereotypical attitude which depicts women as devilish and mischievous has been alluded to in Sadiqi's (2008 a) argument that women in Morocco have been associated with the 'evil eye' to the point that 'if, for example, a person gets hurt, loses something, or hears bad news after having met or spoken to a woman, this person would readily attribute the mishap to the woman" (p. 13).

The subliminal ideology behind this continuous depiction of women in less highstatus jobs, and being clustered more commonly in domestic domains is perhaps to justify their exclusion from taking any active part in decision-making and leadership positions, and 
may at the same time explain the textbook designers' 'hidden agenda' in bringing to the fore man's dominance, protection and hegemony. Women are thus represented as powerless, socially and psychologically inferior being in dire need of man's supervision, care and control.

The findings of this study seem to corroborate prior research arguments that mainstream media discourse has accentuated women's invisibility. In line with this, MEFL textbooks seem to have marginalized the contribution of women, and are therefore far away from any adequate reflection of women's real occupations and accomplishments. This may surely inhibit both girls and boys' worldviews regarding who they are and what are their true aspirations for the future.

The type of gendered messages transmitted to students through these pictorial images tends to perpetuate certain attributes as being highly associated with either males or females. This pattern of representation might have been deployed, intentionally or not, as an effort to draw our attention away from the actual contribution of women as professional and managerial leaders, and seems to evoke and over-emphasize merely their indoor duties.

Subsequent research indicates that continuous exposure of students to such biased representations may surely induce them to formulate inappropriate conclusions regarding their future participation in high managerial positions (Sunderland, 1994; Lee and Collins, 2010; Good et al., 2010).

\section{Conclusion}

The overall results of this study have clearly indicated that the range of work activities, free activities and social activities assigned to the visual representation of female characters is very limited if compared with that of men. The only activities where women seem to be more predominant are the ones which connect them with domestic life taking care of children, preparing meals, washing the dishes, worrying about the education of children, shopping, subject to programs fighting illiteracy and poverty, and being subservient and assistant to men.

Another finding of this research tends to suggest that endorsing a bi-modal analysis combining between the tools of content analysis along with critical image analysis proves to be of a more explanatory adequacy as it has helped unravel a host of many subtle issues of sex stereotyping in textbooks that would not have been made possible to pin down had we used merely one single approach. This implies also that understanding the tools of critical image analysis may provide the researcher with a more enhanced interpretation of the photographic data accounting not only for the overt messages of visual images, but also their covert ideological implications. Critical image analysis (Giaschi, 2000; Newfield, 2011) lies at the core of visual literacy, and its research techniques are far more likely to help facilitate the reading and interpretation of any visual communication.

Briefly stated, it is very unfortunate to contend that the predominance of sex bias in the visual discourse of these textbooks seems to run against the guidelines and recommendations of the National Chart of Education in Morocco (Sabir, 2005), which sets its primary mission to empower foreign language learners, irrespective of their sex, color or ethnic background, through developing their communicative grasp of the four language skills, and preparing them to become equal citizens enjoying all their rights as human 
beings. This may surely be more conducive to the building up of a more egalitarian society where such values as equality of opportunity, women empowerment, tolerance and acceptance of the other should most prevail.

\section{References}

\section{Primary Sources}

[1] Bouddouch,H., M, Ahellal and S, Messaoudi.(2010). Visa to the World. Dar Nachr Almaarifa.

[2] Hammani,M,. S, Ahssen, and L, Tansaoui.(2009). Ticket to English. Book1. DIO.El Hadita.

[3] Hammani,M,. S, Ahssen, and L, Tansaoui.(2009). Ticket to English. Book2. DIO.El Hadita.

[4] Hassim,M., M,Blibil, and A,Ramsmy.(2010). Gateway to English.Book1. Nadia Edition.

[5] Hassim,M., M,Blibil, and A,Ramsmy.(2010). Gateway to English.Book2. Nadia Edition.

[6] Mejber,R,. B,Bagui,. A,Kessab, and M,Oujjani.(2008). Al Massar: Window on the World. Nadia Edition.

[7] Najbi,M,.and E, El Haddad.(2008). Insights into English. El Massar Edition.

[8] Oulbouch,A,. M,Yacine,. B,Moussabbir,. And N, Drissi Chbihi.(2008). Focus. Nadia Edition.

[9] Oulbouch,A,. and M,Yacine.(2006). Outlook. Inter Graph.

\section{Secondary Sources.}

[10] Amini, M. and Birjandi, P. (2012). "Gender bias in the Iranian high school EFL textbooks".English Language Teaching. Vol. 5, No. 2.

[11] Anderson, D., Broaddus, M., Hamilton, M., \& Young, K. (2006). “Gender stereotyping and underrepresentation of female characters in 200 popular children's picture books: A Twenty-first century update". Sex Roles, 55, 757-765.

[12] Association of College and Research Libraries, "ACRL Visual Literacy Competency Standards for Higher Education". American Library Association (October 2011). http://www.ala.org/acrl/standards/visualliteracy Retrieved: June 18, 2014.

[13] Babaii, E., \& Ansary, H. (2001). The Structure of and Stricture on TV Commercials in Iran. Paper Presented at the $5^{\text {th }}$ Conference on Theoretical and Applied Linguistics, Allame Tabataba'ii University, Tehran, March 13-15, 2001.

[14] Bazler, J. A., \& Simonis, D. A. (2006). "Are high school chemistry textbooks gender fair?". Journal of Research in Science Teaching, 28, 353-362.

[15] Benattabou,D.(2014). "Gender imbalances in the Moroccan EFL textbooks: From 'survival of the fittest' to 'survival of all"'. Proceedings of the International Conference on Media, Culture and Education, held in 23-25 November/2010 at the Faculty of Arts and Humanities, Meknes.

[16] Benattabou, D. (2015). Sex Differences and Foreign Language Learning: A Content Analysis of Sex Stereotypes in Moroccan EFL Textbooks. Unpublished PhD. Dissertation, Moulay Ismail University, Meknes..

[17] Bristor, V.J. and Drake, S.V. (1994). "Linking the language arts and content areas though visual technology”. T.H.E. Journal 22 (2), (pp. 74-78).

[18] Davoodi, M. (1999). Language and Culture in Iranian High School English Textbooks. Online published paper. Shiraz University, Iran.

[19] Dube, B. (2006). Illustrations as vehicles of gender stereotyping: An analysis of selected primary school readers in Zimbabwe and South Africa. Paper prepared for the FOTIM Gender Studies Conference, Pretoria, 17 to 19 January 2006.

[20] Duchak, Oksana. (2014). "Visual literacy in educational practice". Czech-Polish Historical and Pedagogical Journal, 6/2, 41-48.

[21] Giaschi, P. (2000). "Gender positioning in education: A critical image analysis of ESL Texts". TESL Canada Journal, 18(1), (pp. 32-46).

[22] Giorgis, C, et al. (1999). "Visual literacy”. Reading Teacher, 53 (2), (pp. 146-153). 
[23] Good, G, Woodzicka, JA and Wingfield, LC (2010). "The Effects of gender stereotypic and counter-stereotypic textbook images on science performance”. The Journal of Social Psychology, 150(2), 132-147oac.

[24] Gooden, A., \& Gooden, M. (2001). "Gender representation in notable children's picture books: 1995-1999”. Sex Roles, 45(1/2), 89-101.

[25] Harris, B. \& Lighter, J. (1980). "The Image of women in Abnormal Psychology: Professionalism versus Psychotherapy”. Psychology of Women Q. 4(3): 396-409.

[26] Hogben, M., \& Waterman, C. (1997). "Are all of your students represented in their textbooks? A content analysis of coverage of diversity issues in introductory psychology Textbooks". Teaching of Psychology, 24, 95-100.

[27] Kang, M.E. (1997). “The portrayal of women's images in magazine advertisements: Goffman's gender analysis revisited”. Sex Roles, 37(11/12), 979-996.

[28] Kress, G., \& van Leeuwen, T. (2006). Reading Images. The Grammar of Visual Design. 2nd Edition. London: Routledge.

[29] Lee, J. F. K. and Collin, P. (2010). "Construction of gender: A comparison of Australian and Hong Kong English language textbooks”. Journal of Gender Studies, Vol. 19, No. 2, 121-137.

[30] Levine, D., and O' Sullivan, M. (2010). "Gender and images in the EFL textbook Talk A Lot, Starter Book, Second Edition”. The Journal and Proceedings of GALE 2010 Vol. 3.

[31] Mathuvi, Ireri, A.M., Mukuni, D.M. Njagi, A.M. and Karugu, N.I. (2012). An analysis of gender displays in selected children picture books in Kenya Philomena N. International Journal of Arts, 2(5): 31-38.

[32] Maxwell, J. A. (2005). Qualitative Research Design: An Interactive Approach. (2nd ed.). Newbury Park, CA: Sage.

[33] Mwetulundila, P. N.(2002). "Why girls aren't fit fully participating in science and mathematics in Namibia". In Reform Forum. Retrieved June 22, 2014 from www.Nied.edu.na/ journals.pdf.

[34] Newfield, D. (2011). "From visual literacy to critical visual literacy: An analysis of educational materials". English Teaching: Practice and Critique May, Volume 10, Number 1.

[35] Omran, K. (2006). "The Images of Women and Men: An analysis of the Contents of Some Textbooks in the Ryrian Arab Republic". Paper presented at the "Woman in Syria Today" Conference. Rida Said Hall, Damascus University.

[36] Reza Adel, S,M and Enayat, M, J. (2016). "Gender representation and stereotyping in ESP Textbooks". The Asian ESP Journal, Vol. 12, Issue 3, December, 2016.

[37] Sabir,A. (2005) 'Review of Moroccan School Textbooks for Gender Equality and Human Rights: Project Results". Retrieved on 13-10-2010 From.http://www.achr.nu/newen63.htm.

[38] Sadiqi, Fatima. (2008a). "Stereotypes and women in Moroccan culture”. Cadernos Pagu 30: 11-32. Retrieved on 13-10-2010 From www://dx.doi.org/10.1590/S0104-83332008000100003.

[39] Sadiqi, Fatima. (2008b). "Gender perception in Moroccan culture. Cultural and civilizational Realities”. Volune 5-Langue Anglais. Bilingual Anglais.

[40] Sadker, M., and Sadker, D. (1994). Failing at Fairness: How America's Schools Cheat Girls. New York, NY: Charles Scribner's Sons.

[41] Sakita, T. I. (1995). "Sexism in Japanese English education: A survey of EFL texts". Woman and Language. 18, (pp. 5-12).

[42] Sunderland, J. (1994). Introduction. In J. Sunderland (ed.), Exploring Gender: Questions and Implications for English language education. London: Prentice Hall.

[43] Tajeddin Zia and Enayat Mostafa Janebi. (2010). "Gender representation and stereotyping in ELT textbooks: A critical image analysis”. TELL, Vol. 4, No. 2, Fall \& Winter 2010, pp. 51-79

[44] Van Leeuwen, T. (2008). Discourse and Practice: New Tools for Critical Analysis. Oxford Studies in Sociolinguistics. Oxford University Press.

[45] Weitzman, L., Eifler, D., Hokada, E., \& Ross, C. (1972). "Sex-role socialization in picture books for preschool children”. American Journal of Sociology, 77(6), (pp. 1125-1150).

[46] Wileman, R. E. (1993). Visual Communicating. Englewood Cliffs, N.J.: Educational Technology Publications. 
[47] Ziad Khalid andOuahmiche Ghania. (2019). "Gender positioning in the visual discourse of Algerian secondary education EFL textbooks: Critical image analysis vs. teachers' perceptions”. Journal of Language and Linguistic Studies, 15(3) (2019) 773-793. 